ARTICLE

\title{
Effectiveness of public university expansion in Brazil: comparison between the situation of graduated and dropout students
}

\author{
Alexandre Nascimento de Almeida ${ }^{a}$ \\ Ivonaldo Vieira Neres ${ }^{b}$ \\ André Nunes ${ }^{c}$ \\ Celso Vila Nova de Souza Júnior ${ }^{d}$
}

\begin{abstract}
Starting in 2007 with the implementation of the Support Program to Restructure and Expansion Plans of Federal Universities (Reuni, acronym in Portuguese), Brazil doubled the number of admissions in public higher education within a decade, while also making the admissions process more inclusive. However, this rapid expansion has led to criticism regarding the loss of quality in public higher education. The objective of this study is to compare the labor market performances of successful graduated and dropout students who majored in four disciplines that encompass this expansion policy. The nonparametric Binomial and Mann-Whitney tests were used to compare the performances of the groups of students who had successfully graduated and those who had dropped out of their courses at the Planaltina campus of the University of Brasilia (UnB-FUP). The performance of the graduated students in our sample was worrisome, as our results show that there is a high number of unemployed students and, that among those employed, few work in the area they majored in, raising doubts about the effectiveness of the policy to expand the number of admissions in higher education held in Brazil.
\end{abstract}

Keywords: Higher education. Social inequality. Alumni research. Educational politics.

\footnotetext{
a Universidade de Brasília, Brasília, DF, Brasil.

b Universidade de Brasília, Brasília, DF, Brasil.

c Universidade de Brasília, Brasília, DF, Brasil.

d Universidade de Brasília, Brasília, DF, Brasil.
} 


\section{Introduction}

In the last decade, Brazilian higher education has undergone a strong expansion process, highlighting the Program of Support for Restructuring and Expansion Plans of Federal Universities (Reuni) as the main policy for this process. This expansion of vacancies was accompanied by democratization policies in the occupation of vacancies giving priority to low-income students, through policies of: expansion of differentiated selective processes for low-income students, creation of night courses or courses in peripheral and low-income regions, investment expansions in student assistance programs, among others.

The Reuni, published through Presidential Decree $n^{0} 6096 / 2007$, has the following objectives: to increase the completion rate of undergraduate courses to $90 \%$; to increase the number of undergraduate students at federal universities; to increase the number of students per teacher in each undergraduate classroom; and to diversify the modalities of undergraduate courses by making more flexible curricula, creating short and distance education courses, encouraging the creation of a new qualifications system and student mobility between institutions (public or private). All these actions should be carried out within five years (BRASIL, 2007).

The Reuni emerged in a favorable economic context and after the re-election of a government with left-center political orientations. It consolidated the view that the Federal Universities have a role in combating social inequalities through democratic access and permanence of students with socioeconomic vulnerability (LIMA; MACHADO, 2016).

The Reuni ended in 2012, still in a center-left government, but at a time of economic slowdown and the beginning of a fiscal crisis that affected public investment capacity, including the education area. According to Tokarnia (2018), resources for investment in federal universities in 2018 decreased to almost a quarter of the value for the same purpose in 2013 , reducing from $\mathrm{R} \$ 3.3$ billion to R\$ 786 million.

Reuni's objectives for the expansion of higher education vacancies were achieved, resulting in an increase in the number of students in public higher education from 336,223 in 2007 to 534,361 in 2015, representing an increase of 59\% (INEP, 2017). However, this rapid expansion has led to a mistrust regarding the quality of education, with criticisms about unplanned course offers, often unattractive and unrelated to the socioeconomic reality of each 
region, resulting in a large number of graduated students outside the labor market (SANTOS et al., 2011).

In this context, as presented by Sousa et al. (2011), the alleged educational inclusion promoted by the Reuni can be criticized and interpreted in the opposite way, that is to say, instead of including the student, it excluded him from the possibility of access to a quality and emancipatory higher education.

Despite the efforts made by the Ministry of Education (MEC) to evaluate the quality of undergraduate courses, the indicators used have been limited (ADRIOLA; ARAUJO, 2018), as they do not assess the impact of higher education on the life of the student and society, increasing the importance of research with graduates to fulfill this purpose. The participation of the graduated students in the evaluation of the quality of a course is fundamental, since it is the graduated student who lives the reality of the labor market and can contribute by pointing out what in his education contributed positively or negatively in his life and professional career. Furthermore, the evaluation of the graduated student situation also contributes to the understanding of the previous dropout of the courses, since the failure of the graduated student in the labor market influences the decision of the current students to continue studying or to drop out.

Thus, looking at Moraes and Kalnin (2018), the objective of the study is to compare the situation between the graduated students and dropouts for the courses of the UnB campus of Planaltina between 2006 and 2014. The FUP reflects the Reuni proposal, aiming to attend a peripheral area of Brasília with courses in the daytime, night and alternation regime. The specific objectives are: 1) to compare the rate of graduated students and dropouts who are working, studying and looking for a job; 2) to analyze the alignment between the employability of the graduated student and his graduation area; 3 ) to compare the job opportunities and the remuneration in the labor market among the graduated students and dropouts.

\section{Theoretical reference}

The research with graduated students has acquired a great centrality in the public educational policies, mainly by the governmental organisms, with the purpose of amplifying the control and inspection actions on the educational institutions. According to Brandalise (2012), the feedback of the graduated students concerning the education offered by an institution is necessary for the proposition of changes in the curricula, in the processes of teaching learning, 
in the university management and to ascertain the professional and academic trajectory after the conclusion of the course.

To Teixeira et al. (2015), graduated students studies have been conducted since the 1930s in the United States, with studies related to job satisfaction, the relationship between universities and the labor market, and the transition from academic to professional life. The graduate evaluation can be a very important indicator for the institutional diagnosis, since it is based on the personal and professional maturity of the former student, who has a more holistic view about the university in which $\mathrm{s} / \mathrm{he}$ graduated.

According to Castro and Teixeira (2014), the graduated students' knowledge makes it possible to analyze the training and allows knowing and identifying other issues, such as: insertion in the labor market, work processes, personal satisfaction with work, causes that lead to changes in activity, motivators for continuity in studies, among others.

Another set of research in the area of education deals with the issue of student dropout. According to Figueiredo and Salles (2017), dropout research presents a very diverse conceptual framework, with definitions that do not always dialogue with each other, creating ambiguity and/or limitation to the analyses. The author tries to understand the causes of the dropout, is faced with a complex phenomenon, but emphasizes the importance of a formation oriented to the emancipation of the student. Prestes and Fialho (2018) identified an increase in dropout rates after the Reuni program, reaching conclusions aligned with Sousa et al. (2011) and Figueiredo and Salles (2017), since it associated school success with the possibility of emancipation of the individual, including financial emancipation.

\section{Methodology}

\subsection{Study area}

The research was developed at the University of Brasilia (UnB) on the campus of the city of Planaltina (FUP). UnB was a pioneer in the expansion of higher education process in Brazil and, with the assistance of its own expansion plan and Reuni support, created three new campuses on the outskirts of Brasilia, at the cities of Planaltina, Ceilândia and Gama.

The UnB campus in Planaltina began its activities in 2006 with 10 faculty members and 70 students enrolled in the course of Degree in Natural Sciences 
(LCN) and Bachelor in Agribusiness Management (Gagro). In 2007, after joining the Reuni, the FUP increased the number of vacancies with the creation of three more undergraduate courses, with a course of Degree in Field Education (Ledoc), and in 2008, were inaugurated the Bachelor in Environmental Management (GAM) and another course in LCN, but during the night shift (SARAIVA; DINIZ, 2012). In 2014, the FUP had approximately 100 faculty members, slightly more than 1000 students and 38 technical-administrative public servants (UnB, 2015).

\subsection{Data}

Data collection for this research came from the electronic questionnaire for the population of graduated students and dropouts of all FUP courses between the 1 st half of 2006 and the $2^{\text {nd }}$ half of 2014. The data for the LCN courses for the day and night periods were aggregated and analyzed together.

The questionnaires were sent by e-mail and randomly between June and August 2015 to a population of 597 graduated students and 768 dropouts. After the questionnaire was sent, all the students in the sample population were contacted by telephone, explaining the objectives and the importance of the research.

Except for the Ledoc course and, especially, in the sample of graduated students, the number of questionnaires answered reached almost half of the population sampled. In the group of dropouts this percentage was $23 \%$ and for the Ledoc course were sampled $26 \%$ of the graduated students and $9 \%$ of the dropouts. The relationship between sample size and population was in accordance with the suggestions of Nazareth (1999). According to the author, the representativeness of the sample should be guaranteed by approximately $10 \%$ of the size of the target population (Table 1).

Table 1 - Population and sample of the research

\begin{tabular}{lcccc}
\hline & \multicolumn{2}{c}{ Graduated } & \multicolumn{2}{c}{ Dropout } \\
\cline { 2 - 5 } & Population (N) & Sample (n) & Population (N) & Sample (n) \\
\hline GAM & 91 & 43 & 98 & 27 \\
Gagro & 193 & 88 & 155 & 25 \\
LCN & 188 & 76 & 301 & 79 \\
Ledoc & 125 & 32 & 214 & 19 \\
FUP & 597 & 239 & 768 & 150 \\
\hline
\end{tabular}

Source: FUP (2016) 


\subsection{Questionnaire}

The questionnaire was composed of three questions that evaluated the situation of the graduated student and dropout. Moreover, the graduated students who declared to be working answered another question that approached the alignment of their current occupation with the training acquired in the FUP (Chart 1).

References that contributed to the preparation of the questionnaire are based on graduated students research aimed at undergraduate courses, highlighting: Morgado et al. (2011), Prado Filho et al. (2013) and Silva et al. (2011).

\section{Chart 1 - Questionnaire applied}

\section{SITUATION OF THE GRADUATED AND DROPOUT STUDENT}

1. What is your occupation at the moment?

( ) Working ( ) Looking for a job or studying for a public tender

( ) Studying to enhance the curriculum (postgraduate, specialization, other graduation, etc.)

( ) Neither working, studying nor looking for a job ( ) Other:

2. Regarding the number of opportunities, how do you evaluate the labor market to your skills?
( ) Rare opportunities
( ) Few opportunities
( ) Reasonable opportunities
( ) Many opportunities
( ) Too many opportunities

3. Potential gain - How much can you earn in the current market?
( ) Up to R\$1,500
( ) Between R\$1,501 and 2,000 ( ) Between R \$2,001 and 2,500
( ) Between R\$2,501 and 3,000 ( ) Between R\$3,001 and 3,500 ( ) Between R\$3,501 and 4,000
( ) Between R\$4,001 and 4,500 ( ) Between R\$4,501 and 5,000 ( ) Between R\$4,001 and 6,500
( ) Between R\$4,001 and 6,500 ( ) Between $R \$ 4,501$ and 5,000 ( ) Between $R \$ 5,001$ and 6,500
( ) Between R \$7,001 and 7,500 ( ) Between R\$7,501 and 8,000 ( ) Above R \$8,001

\section{QUESTION ONLY FOR GRADUATED STUDENTS}

4. If you are working, indicate the relationship of the current job with the training in the FUP.

( ) Working in the area where he graduated from the FUP.

( ) Partially working in the area where he graduated from the FUP.

( ) Working outside the area in which he graduated from the FUP. 


\subsection{Comparison between the situation of the graduated with the dropout from FUP}

The methods employed to compare the situation between the graduated and dropout were the nonparametric Binomial test and the Mann-Whitney U-test. These tests were chosen because of the adherence of their methods with the scale of measurement of the questions in the questionnaire, since the Binomial test is suitable for variables measured in nominal scale and the U-test for ordinal scale. The significance level allowed for both tests was up to $10 \%$.

The Binomial test compared the frequencies between dropout and graduated students who are: working, looking for a job, studying to enhance the curriculum or doing nothing (neither working, studying nor looking for a job).

Within the group of graduated students who are employed, there are those who are working in the area, partially in the area or outside the graduation area. The Binomial test was also used to compare whether the proportions of those working in the area are different from those working outside the graduation area. Moreover, those who are working at least partially in the degree area (sum of the percentages of those who declared to be partially working and in the degree area) are different from those who are working outside the degree area.

The Mann-Whitney U-test compared the perception among the dropouts and graduated students regarding work opportunities and the potential gain of each group.

\section{Results and discussions}

\subsection{Situation of the Graduated and Dropout Student}

The graduated and dropout student's situation for all courses of the FUP were presented in Figure 1. Except for the option "neither working, looking for work nor studying", which had a negligible percentage of students in this situation, all other options were well represented.

The statistical results for the comparison between the graduated students' situation with the dropout student are found in Table 2. In general, the results for the FUP were in accordance with the results of the Gagro and LCN courses, reflecting the greater aggregated representativeness of these courses in the FUP. The GAM and Ledoc courses presented some results that were different from the campus average. 
Figure 1 - Situation of the graduated and dropout student for FUP courses

FUP

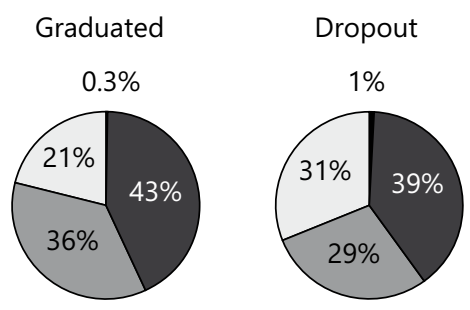

Agribusiness Management

Graduated

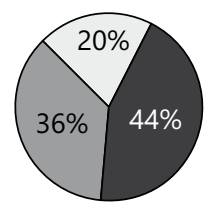

Degree in Field Education
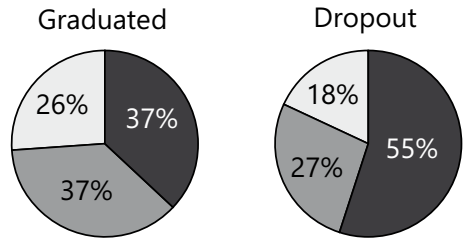

Source: Prepared by the authors (2016)

Environmental Management

Graduated

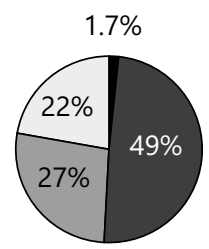

Degree in Natural Sciences

Graduated
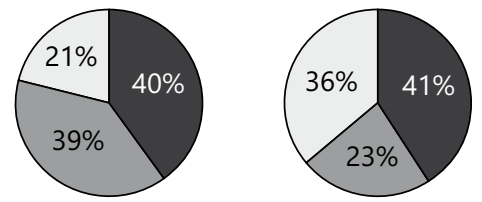

Working

Looking for a job

Studying to enhance the curriculum

Neither working, studying nor

looking for a job

According to the aggregated results for the FUP, the percentage of the graduated students who are looking for a job is statistically higher than the dropout's rates; moreover, it was not possible to affirm that the percentage of the graduated students that are working is greater than the dropout percentage. On the other hand, the number of the dropouts who are doing nothing (neither working, nor looking for a job nor studying) was statistically higher than the number for the graduated students in this situation.

Among the reasons that explain the higher percentage of graduated students seeking employment may be the greater financial difficulty of the dropout students and, 
Table 2 - Comparison between the situation of the graduated and dropout student.

\begin{tabular}{|c|c|c|c|c|}
\hline & \multicolumn{2}{|c|}{ Working } & \multicolumn{2}{|c|}{ Looking for a job } \\
\hline & Graduated & Dropout & Graduated & Dropout \\
\hline FUP & $43.0 \%$ ns & $39.0 \%$ ns & $36.0 \%^{2}$ & $29.0 \%^{2}$ \\
\hline GAM & $49.0 \%^{2}$ & $35.0 \%^{2}$ & $27.0 \%^{2}$ & $40.0 \%^{2}$ \\
\hline GAGRO & $44.0 \%{ }^{\mathrm{ns}}$ & $33.0 \%$ ns & $36.0 \%{ }^{\mathrm{ns}}$ & $31.0 \%$ ns \\
\hline LCN & $40.0 \%$ ns & $41.0 \%$ ns & $39.0 \%^{1}$ & $23.0 \%^{1}$ \\
\hline \multirow[t]{3}{*}{ LEDOC } & $37.0 \%^{3}$ & $55.0 \%^{3}$ & $37.0 \%{ }^{\mathrm{ns}}$ & $27.0 \%$ ns \\
\hline & \multicolumn{2}{|c|}{ Studying to enhance the curriculum } & \multicolumn{2}{|c|}{$\begin{array}{l}\text { Neither working, studying } \\
\text { nor looking for a job }\end{array}$} \\
\hline & Graduated & Dropout & Graduated & Dropout \\
\hline FUP & $21.0 \%^{1}$ & $31.0 \%^{1}$ & $0.3 \%^{3}$ & $1.0 \%^{3}$ \\
\hline GAM & $22.0 \%$ ns & $22.0 \%$ ns & $1.7 \%$ ns & $2.5 \%$ ns \\
\hline GAGRO & $20.0 \%^{2}$ & $33.0 \%^{2}$ & $0.0 \%^{2}$ & $2.8 \%^{2}$ \\
\hline LCN & $21.0 \%^{1}$ & $36.0 \%^{1}$ & $0.0 \%$ ns & $0.0 \%^{\mathrm{ns}}$ \\
\hline LEDOC & $26.0 \%$ ns & $18.0 \%$ ns & $0.0 \%$ ns & $0.0 \%$ ns \\
\hline
\end{tabular}

FUP: University of Brasilia (UnB) on the campus of the city of Planaltina; GAM: Bachelor in Environmental Management; Gagro: Bachelor in Agribusiness Management; LCN: Degree in Natural Sciences; Ledoc: Degree in Field Education.

${ }^{n s}$ (not significant) Indicates that the proportions between graduated and dropout are equal.

1,2,3 (significant at the 1, 5 and $10 \%$ level) Indicates that the proportions between graduated and dropout are different.

Source: Prepared by the authors (2016)

consequently, their less resistance in accepting jobs with low remuneration. That happens because the financial deficiency of students is one of the main reasons that lead to drop (BAGGI; LOPES, 2011; FIGUEIREDO; SALLES, 2017; GOMES et al., 2010). Other variables that affect dropout rates can be found in Ferrão and Almeida (2018).

In addition to the greater financial urgency of dropouts, difficulties for the graduated students to find jobs in their degree area may have contributed to the higher percentage of unemployed graduated students. According to Saraiva and Diniz (2012), the FUP courses can be considered innovative because they have focus, methodological approach and multidisciplinary curricular grades. However, they are not traditional courses and are still poorly recognized, making it difficult to enter the labor market.

The disaggregated results for the GAM course indicated a contrary tendency to FUP. In the course of GAM the percentage of graduated students working was 
higher than that of the dropout and the number of graduated students seeking employment was lower than that of the dropout. The explanation of these results is related to the fact that the GAM course takes place during the night period and that aspect facilitates a reconciliation between study and work. Thus, in case of not being able to get a job in the degree area after graduating, it is probable that the GAM graduated student will continue in the same job as $\mathrm{s} / \mathrm{he}$ did during the degree.

Although higher than the FUP average, the number of GAM graduated students inserted in the labor market was lower compared to that found by Morgado et al. (2011) in a research carried out for the GAM course of the University of Sao Paulo (USP). Morgado et al. (2011) identified that $72 \%$ of the graduated students of this course are inserted in the labor market, a value higher than the $49 \%$ for the GAM graduated from the FUP. The greater employability of USP environmental managers is explained by the great demand of the private and industrial sector in the city of Sao Paulo. Unlike Sao Paulo, Brasilia is an administrative city with an inexpressive industrial activity.

From a graduated students research for the course of Environmental Engineering from the Federal University of Ouro Preto (Ufop), a degree with similar assignments to the GAM course, Prado Filho et al. (2013) identified that $76.5 \%$ of graduated students found employment in the degree area in the first year of training, rising to $89.2 \%$ with up to two years of training. The authors also found that, similar to results Morgado et al. (2011), more than half of the graduated students (55.3\%) work in private companies.

Unlike the GAM graduated students, those from Ledoc had a greater difficulty entering the labor market, since only $37 \%$ of their graduated students declared to be working. Furthermore, this value was statistically lower than the percentage of the dropouts who reported being employed (55\% of the answers). Probably, the financial urgency inherent to the dropout student and the lack of perspective of the graduated students weigh more in the course of Ledoc than in the other courses of the FUP. Since, in general, students of Ledoc have a more fragile economic situation and come from a rural area with little dynamics and reduced opportunities for skilled jobs.

The lack of market for Ledoc graduated students is consequence of the small number of rural schools for this professional, the competition with other educators in the rural schools and the fact that the course is new and little known in the market. In addition, Molina and Rocha (2014) pointed out that more than 32 thousand rural 
schools were closed in the last ten years, reducing from 102 thousand schools in 2002 to 70 thousand in 2013. This reality represents a reduction in the offer of jobs for the countryside educator and is misaligned with the growth in the creation of courses of this nature in recent years, which began to be implemented in 2006 and in 2015, already accounted for with 94 Ledoc courses in Brazil (BRASIL, 2015; HANFF et al., 2013).

The insertion in the job market of the graduated students and dropouts for the Gagro course were statistically the same and, as for the other courses, less than half of the graduated students declared to be working ( $44 \%$ of the graduated students).

Similar to the results for GAM, the location of Gagro courses in regions with strong industrial and private activity seems to be determinant for the employability of their graduated students. Santos Neto and Azevedo (2013) carried out a research with the students of the courses of GUP of the FUP, the State University of Campinas (Unicamp) and the Federal University of Viçosa (UFV), aiming to verify the area of action in the student preference. While $58.6 \%$ of FUP students said they want to work in the private sector, the same percentage for Unicamp and UFV courses was $82.5 \%$ and $72.1 \%$.

In order to succeed in the job market it is essential that the professional has the appropriate qualification to act in the desired area. However, there are other variables that can contribute to increase the chances of insertion in the labor market. For this, the professional must be in tune with what the market demands. According to Macedo et al. (2015), the Gagro professional, given the complexity of the sector, must gather technical knowledge of agroindustrial production with the ability to manage and at the same time looking beyond the limits of productive chains.

Regarding the LCN course, the results indicated that the percentage of graduated students who are looking for a job is higher than the dropouts' rate in the same situation, suggesting a difficulty for the inclusion of these graduated students in the labor market. The factors that can explain this difficulty are: quality and prestige of the course, ability and commitment of the graduated students, availability of the labor market, among others.

The graduated student at LCN can act as elementary and middle school teacher in public or private schools; however, the discipline of Natural Sciences does not exist in high school, being divided between Physics, Chemistry and Biology. 
In case of teacher shortage in the fields of physics, chemistry and biology, those trained in LCN can teach to classes in high school.

According to Mello (2008), a LCN course, even those of high quality, is not able to provide specific training in Physics, Biology or Chemistry simply because it was not designed so. The author also stressed the importance of teaching institutions to not create expectations towards high school activities for the LCN graduated student and that the student needs to clearly understand that s/he will be entering a teacher training course for elementary school.

Except for the GAM and Ledoc courses, the results indicated that the percentage of dropouts who have been studying to enhance the curriculum was higher than that of graduated students. These results are not surprising, since although some graduated students are doing postgraduate studies and continuing their studies, one of the main reasons for students' drop is their willingness to change courses. To a large extent, this change in course occurs because students are admitted to more traditional courses at $\mathrm{UnB}$ or because they can get a scholarship to study in private college in a course of greatest interest to them or that is closer to their home.

The percentage of FUP students who chose to continue their studies after graduation was $21 \%$. These results were similar to that found by Prado Filho (2013) and lower than Morgado et al. (2011). Prado Filho (2013) identified that $27.2 \%$ of the graduated students of an Environmental Engineering course immediately enrolled in post-graduate (specialization and master's degree) after graduation. In the research Morgado et al. (2011), 47.7\% of the graduated students declared to have attended or are attending a postgraduate course, a number considered to be high by the authors of the research.

In general, graduated students surveys showed that well over half of the graduated students entered the labor market within the first year after graduating, suggesting that the FUP has difficulty in this aspect for all courses, even with all the limitations inherent of this comparison because of the different locations and time period between surveys (MORGADO et al., 2011; PRADO FILHO et al., 2013 ).

The results about the situation of the FUP student suggested an unfavorable situation of the graduated students compared to the dropouts, mainly because the percentage of the dropouts who are looking for work is smaller when compared to graduated students' rate, and the statistical test is not sufficient to affirm that the percentage of the graduated students who are working is greater than the 
dropouts' percentage. However, caution is required in interpreting these results, and it is necessary to address at least two more variables in this analysis: 1) what is the alignment between the work and the degree area of the FUP graduated student? 2) what is the potential and value of the graduated students and dropouts in face of the labor market?

\subsection{Job alignment with the degree area at FUP}

Among the graduated students who are employed, approximately half of them declared to be working in their degree area, except for the GAM course, where this percentage decreased to about $1 / 4$ of the graduated students (Figure 2).

Figure 2 - Alignment between work and the training of graduated students of FUP courses

FUP

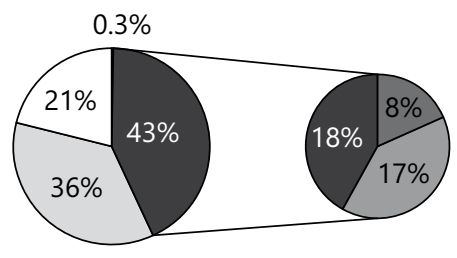

Agribusiness Management

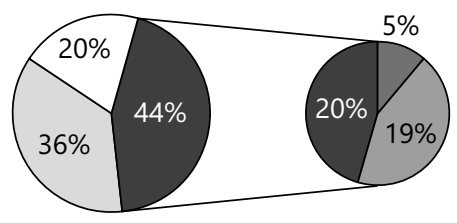

Degree in Field Education

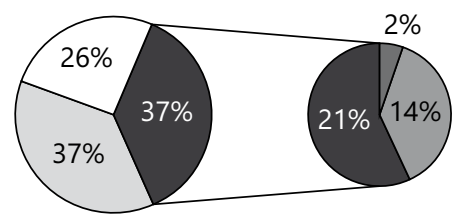

Environmental Management

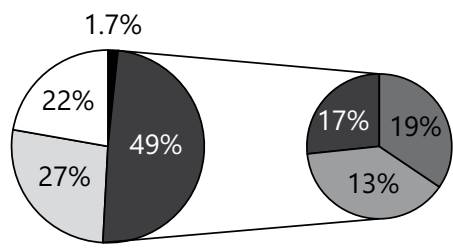

Degree in Natural Sciences

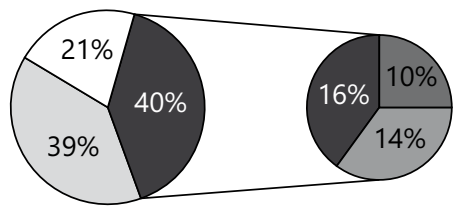

Looking for a job

Studying to enhance the curriculum

Working in the area

Working partially in the area

Working outside the area

Neither working, looking for a job

Source: Prepared by the authors (2016) 
The results of the statistical comparisons of the U-test among the graduated students who are working in the area or at least partially in the area against those which are working outside the training area are in Table 3.

Statistical aggregate results for FUP and disaggregated for all campus courses, have failed to state that the percentage of graduated students who are working in their degree area is higher than those who are working outside the area. However, the percentage of graduated students who are working at least partially in the area was statistically higher than those who declared that they were working outside the degree area, according to the results of the cluster analysis for the FUP and for the LCN course.

The graduated students who are working at least partially in their degree area, in most cases, are developing management activities not related to the environment or agribusiness areas or they became faculty members that teach unrelated disciplines with what they learned at the course. These results are due in part to the multidisciplinary nature of the FUP courses, which enable a broad and generic student degree, allowing greater dynamism in the entrance to the labor market.

The FUP courses were designed to avoid employment problems resulting from seasonality in the market, as pointed out by Riva and Scoeninger (2015). According to these authors, in a world of competitive and globalized jobs, the choices and expectations are laid on the courses that posses high employability or have a lot

Table 3 - Comparative for the alignment of graduate employment

\begin{tabular}{lcccc}
\hline & \multicolumn{4}{c}{ Working } \\
\cline { 2 - 5 } & Area & Outside the Area & Area + Partly in Area & Outside the Area \\
\hline FUP & $18 \%^{\mathrm{ns}}$ & $17 \%^{\mathrm{ns}}$ & $26 \%^{1}$ & $17 \%^{1}$ \\
GAM & $13 \%^{\mathrm{ns}}$ & $19 \%^{\mathrm{ns}}$ & $30 \%^{\mathrm{ns}}$ & $19 \%^{\mathrm{ns}}$ \\
GAGRO & $20 \%^{\mathrm{ns}}$ & $19 \%^{\mathrm{ns}}$ & $25 \%^{\mathrm{ns}}$ & $19 \%^{\mathrm{ns}}$ \\
LCN & $16 \%^{\mathrm{ns}}$ & $14 \%^{\mathrm{ns}}$ & $26 \%^{3}$ & $14 \%^{3}$ \\
LEDOC & $21 \%^{\mathrm{ns}}$ & $14 \%^{\mathrm{ns}}$ & $23 \%^{\mathrm{ns}}$ & $14 \%^{\mathrm{ns}}$ \\
\hline
\end{tabular}

FUP: University of Brasilia (UnB) on the campus of the city of Planaltina; GAM: Bachelor in Environmental Management; Gagro: Bachelor in Agribusiness Management; LCN: Degree in Natural Sciences; Ledoc: Degree in Field Education.

ns (not significant) Indicates that the proportions between graduated and dropout are equal.

$1,2,3$ (significant at the 1,5 and 10\% level) Indicates that the proportions between graduated and dropout are different.

Source: Prepared by the authors (2016) 
of visibility at the moment, or on courses that offer greater chances of professional and economic growth. However, expectations are not always met, the courses become unattractive, the profession can quickly become devalued, the professional practice of the market may go into recession and the graduated students face the frustration of not being able to enter the labor market in the right time.

Among the FUP courses, the GAM graduated students showed greater difficulty in entering the labor market in their degree area. However, the difference between the courses was not large, ranging from $13 \%$ to $21 \%$ rates for graduated students in GAM and Ledoc who reported working in their degree area. However, when compared with the percentage of Unicamp where the GAM graduated students who are working in their degree area amounts to about $61 \%$, the difference stands out.

Corroborating the low employability in their degree area of FUP graduated students, the research of Silva et al. (2011), which sampled 4,431 graduated students of various courses at UFSC, verified that $93.59 \%$ of the graduated students work in their degree area.

The probable reasons for the difference between employment in their degree area at this research are due to different economic dynamics between the regions in which these courses are located, the different economic moments of the analysis and the quality and distinctive characteristics of the compared courses.

\subsection{Job opportunities and potential gain of the graduated and dropout}

As the results presented in Table 4, the perception of the graduated student in the number of job opportunities was lower compared to perception of dropout, except for the Ledoc course where the difference in opinion between the graduated student and dropout was not statistically significant at the $10 \%$ level. In general, while the graduated student assessed the amount of opportunities in his labor market as few, the dropout said that there are reasonable job opportunities.

Still according to the Table 5 results, on the one hand the dropouts appear to have a greater number of opportunities, on the other hand the potential gain was lower. Except for the Ledoc course, wherein the difference in the results were not statistically significant at the $10 \%$ level, the perception of potential gain by the graduated student was equal when compared with the perception of the dropout. 
Table 4 - Comparison between the perception of students who dropped out and about their job opportunities and their earning potential in the labor market

\begin{tabular}{|c|c|c|c|c|}
\hline & \multicolumn{2}{|r|}{ Graduated } & \multicolumn{2}{|r|}{ Dropout } \\
\hline & Median & Category & Median & Category \\
\hline & \multicolumn{4}{|c|}{ FUP } \\
\hline Job opportunities & $2^{1}$ & Few opportunities & $3^{1}$ & $\begin{array}{l}\text { Reasonable } \\
\text { opportunities }\end{array}$ \\
\hline \multirow[t]{2}{*}{ Potential gain } & $4^{1}$ & $\begin{array}{c}\text { Between } R \$ 2,501 \text { and } \\
3,000\end{array}$ & $2^{1}$ & $\begin{array}{c}\text { Between } \mathrm{R} \$ 1,501 \text { and } \\
2,000\end{array}$ \\
\hline & \multicolumn{4}{|c|}{ ENVIRONMENTAL MANAGEMENT } \\
\hline Job opportunities & $2^{1}$ & Few opportunities & $3^{1}$ & $\begin{array}{l}\text { Reasonable } \\
\text { opportunities }\end{array}$ \\
\hline \multirow[t]{2}{*}{ Potential gain } & $4.5^{2}$ & $\begin{array}{c}\text { Between } R \$ 2,501 \text { and } \\
3,000\end{array}$ & $2^{2}$ & $\begin{array}{c}\text { Between } \mathrm{R} \$ 1,501 \text { and } \\
2,000\end{array}$ \\
\hline & \multicolumn{4}{|c|}{ AGRIBUSINESS MANAGEMENT } \\
\hline Job opportunities & $2^{1}$ & Few opportunities & $3^{1}$ & $\begin{array}{l}\text { Reasonable } \\
\text { opportunities }\end{array}$ \\
\hline \multirow[t]{2}{*}{ Potential gain } & $4^{2}$ & $\begin{array}{c}\text { Between } R \$ 2,501 \text { and } \\
3,000\end{array}$ & $2.5^{2}$ & $\begin{array}{c}\text { Between } \mathrm{R} \$ 1,501 \text { and } \\
2,000\end{array}$ \\
\hline & \multicolumn{4}{|c|}{ BACHELOR OF NATURAL SCIENCES } \\
\hline Job opportunities & $2^{1}$ & Few opportunities & $3^{1}$ & $\begin{array}{l}\text { Reasonable } \\
\text { opportunities }\end{array}$ \\
\hline \multirow[t]{2}{*}{ Potential gain } & $4^{2}$ & $\begin{array}{c}\text { Between } R \$ 2.501 \text { and } \\
3,000\end{array}$ & $3^{2}$ & $\begin{array}{c}\text { Between } \mathrm{R} \$ 2,001 \text { and } \\
2,500\end{array}$ \\
\hline & \multicolumn{4}{|c|}{ DEGREE IN THE FIELD OF EDUCATION } \\
\hline Job opportunities & $2^{\mathrm{ns}}$ & Few opportunities & $2^{\mathrm{ns}}$ & Few opportunities \\
\hline Potential gain & $3^{\text {ns }}$ & $\begin{array}{c}\text { Between } R \$ 2.501 \text { and } \\
3,000\end{array}$ & $2^{\text {ns }}$ & $\begin{array}{c}\text { Between } \mathrm{R} \$ 1.501 \text { and } \\
2,000\end{array}$ \\
\hline
\end{tabular}

ns (not significant) Indicates that the proportions between graduated and dropout are equal. $1,2,3$ (significant at 1, 5 and 10\%) Indicate that the proportions between graduated and dropout are different.

Source: Prepared by the authors (2016)

In part, the results were corroborated by the results of the Vizia (2008). According to Vizia (2008), for each year of study in Brazil there is, on average, an increase of $15 \%$ in the employee's income, which explains the expectation of the graduated student to get higher wages compared to the perception of the dropout. On the other hand, Vizia (2008) indicated that the number of years in school does not simply improve the financial aspects but also directly affects the likelihood of finding a job. Also according to the survey, the rate of employed people increased 3.4\% for each year of study, therefore not supporting the more pessimistic perception of the FUP graduate regarding job opportunities. 


\section{Conclusions}

The results related to professional inclusion of the FUP graduated students were worrying, given that less than half of them reported to be working, a number much lower than that found in other studies. Additionally, it was identified that the number of unemployed graduated students is larger than the number of dropouts in the same situation. Although employed graduated students have demonstrated that they can earn more than dropouts, the results did not confirm that the graduated student has access to a greater number of job opportunities compared to students with lower level of education.

Another aggravation in the employment situation of graduated students is the low employability in their degree area of the FUP courses. Although FUP courses are multidisciplinary and theoretically allow greater flexibility for inclusion in the labor market, the percentage of students who reported to be working in the area or in partially in their degree area was lower than the ones observed in other studies. Furthermore, there was no statistically significant difference between the proportions of graduated students who are working in the area and outside their degree area, suggesting a low impact of the training provided by the FUP in the professional lives of their students.

The innovative and multidisciplinary feature of FUP courses can be a good bet for the future but, at present moment, these issues have hampered the employability of its students. Barriers related to the credibility of the courses led the labor market to choose qualified professionals rather than bachelors of GAM and Gagro, as well as led them to give priority to Biology, Chemistry, Physics and Mathematics teachers in science education for elementary education instead of the graduated students in LCN and Ledoc courses.

Another aspect that hinders the employability of FUP students may be related to a condition of low income of many graduated students. This graduated student profile does not have economic conditions to invest in further training and also their contact network is probably not favorable for their professional inclusion, leaving him with unequal conditions for a job search.

The results entice that the cost/benefit of the expansion policy and democratization of higher education places in Brazil, if not well planned and implemented, may lead to unfavorable results and do not contribute to the achievement of its objectives in the long run. Because, beyond the State's cost to offer these vacancies, we cannot lose sight of the opportunity cost of these students and their negative impact on society due to the development of human resources with low quality. 
Perhaps the main difficulty to implement the expansion and democratization of vacancies in the FUP is not the poor recognition of the campus courses, or the fact that the campus is still going through a consolidation phase and neither because of the low income profile of most students. However, all of these variables imply difficulties and, acting together, potentiate the chance of failure in the implementation of any policy of expansion and democratization of higher education.

Increasing the employability of graduated students of the FUP is not a simple task and it is not solely dependent on internal efforts from UnB. Suggestions to minimize this problem are related to the increase in the quality of the courses and orientation to meet the needs of the labor market in a wider geographic reach. Some short-term actions in this direction depends on the commitment of all the elements of the campus for the regulation and inclusion of professions in professional advices, proximity of the courses with public and private sectors, among others.

Faced with the professional frustration of the students, public rumors tend to arise that the FUP formation is useless. The effects of social networks are deleterious in this sense, affecting the image of the courses, the campus and the institution. 


\section{Efetividade da expansão universitária pública no Brasil: comparação entre a situação de alunos egressos e evadidos}

\section{Resumo}

A partir de 2007, com a implementação do Programa de Apoio a Planos de Reestruturação e Expansão das Universidades Federais (Reuni), o Brasil dobrou e democratizou as vagas no ensino superior público no intervalo de uma década. Porém, essa rápida expansão tem levado a críticas quanto à perda de qualidade do ensino superior público. O objetivo do trabalho é comparar a situação no mercado de trabalho entre os alunos egressos com os evadidos de quatro cursos que representam essa política de expansão. Para tanto, empregaram-se os testes não paramétricos da Binomial e de Mann-Whitney para comparar a situação entre os grupos de estudantes egressos e evadidos da Faculdade UnB Planaltina (FUP). Os resultados dos egressos analisados foram preocupantes, demonstrando um alto número de alunos desempregados e, entre os empregados, poucos trabalham na sua área de formação, levantando dúvidas da efetividade da política de expansão de vagas no ensino superior realizada no Brasil.

Palavras-chave: Ensino superior. Desigualdade social. Pesquisa de egresso. Política educacional

\section{Efectividad de la expansión universitaria pública en Brasil: comparación entre la situación de egresados y alumnos que abandonaron}

\section{Resumen}

A partir de 2007, con la implementación del Programa de Apoyo a los Planes de Reestructuración y Expansión de las Universidades Federales (Reuni), Brasil dobló y democratizó las vacantes en la educación universitaria pública en el intervalo de una década. Sin embargo, esta rápida expansión ha llevado a críticas en cuanto a la pérdida de calidad de la educación universitaria pública. El objetivo del trabajo es comparar la situación en el mercado de trabajo entre los egresados y los alumnos que abandonaron cuatro cursos que representan esa política de expansión. Para ello, se emplearon las pruebas no paramétricas Binomial y de Mann-Whitney para comparar la situación entre estos dos grupos en la Facultad UnB Planaltina (FUP). Los resultados de los egresados analizados fueron preocupantes, demostrando que hay un alto número de alumnos desempleados y, que entre los empleados, pocos trabajan en su área de formación, levantando dudas de la efectividad de la política de expansión de vacantes en la educación universitaria realizada en Brasil.

Palabras clave: Educación universitaria. Desigualdad social. Investigación de egresado. Política de educación. 


\section{References}

ADRIOLA, W. B.; ARAUJO, A. C. Uso de indicadores para diagnóstico situacional de instituições de ensino superior. Ensaio: Avaliação e Políticas Públicas em Educação, Rio de Janeiro, v. 26, n. 100, p. 645-663, maio 2018. https://doi.org/10.1590/s0104-40362018002601062

BAGGI, C. A. D. S.; LOPES, D. A. Evasão e avaliação institucional no ensino superior: uma discussão bibliográfica. Avaliação: Revista da Avaliação da Educação Superior, Campinas, v. 16, n. 2, p. 355-374, 2011. https://doi.org/10.1590/S1414-40772011000200007

BRANDALISE, M. A. T. Avaliação dos cursos de graduação na perspectiva dos egressos: um indicador de avaliação institucion al. In: Anped SUL SEMINÁRIO DE PESQUISA EM EDUCAÇÃO DA REGIÃO SUL, 9., 2012, Caxias do Sul. Anais[...] Caxias do Sul: Universidade de Caxias do Sul, 2012.

BRASIL. Decreto n ${ }^{\circ} 6.096$, de 24 de abril de 2007. Institui o programa de apoio aos planos de reestruturação e expansão das universidades federais Reuni. Diário Oficial da União, Brasília, DF, 2007 Apr. 25.

BRASIL. Ministério da Educação - MEC. Sistema E-MEC: cursos de licenciatura em educação do campo - Ledoc. Brasília, DF, 2015.

CASTRO, A. K. S. S.; TEIXEIRA, M. A. P. Evasão universitária: modelos teóricos internacionais e o panorama das pesquisas no Brasil. Psicologia Argumento, Curitiba, v. 32, p. 9-17, 2014. https://doi.org/10.7213/psicol..argum.32.s02.AO01

FERRÃO, M. E.; ALMEIDA, L. S. Multilevel modeling of persistence in higher education. Ensaio: Avaliação e Políticas Públicas em Educação, Rio de Janeiro, v. 26, n. 100, p. 664-683, July/Sept. 2018. https://doi.org/10.1590/s0104-40362018002601610

FIGUEIREDO, N. G. S.; SALLES, D. M. R. Educação profissional e evasão escolar em contexto: motivos e reflexões. Ensaio: Avaliação e Políticas Públicas em Educação, Rio de Janeiro, v. 25, n. 95, p. 356-92, Apr. 2017. https://doi.org/10.1590/s0104-40362017002500397

GOMES, M. J. et al. Evasão acadêmica no ensino superior: estudo na área da saúde. Revista Brasileira de Pesquisa em Saúde, Vitória, v. 12, n. 1, p. 6-13, 2010. 
HANFF, B. B. C.; CEOLIN, T.; BRICK, E. M. Formação inicial de professores por área do conhecimento: o curso de licenciatura em educação do campo da UFSC. In: SIMPÓSIO INTERNACIONAL DE EDUCAÇÃO DO CAMPO DA UFRB, 1., 2013, Amargosa. Anais[...] Amargosa: Universidade do Recôncavo Baiano, 2013.

INSTITUTO NACIONAL DE ESTUDOS E PESQUISAS EDUCACIONAIS ANÍSIO TEIXEIRA - Inep. Sinopses estatísticas da educação superior: graduação. Brasília, DF, 2017. Avaliable from: http://portal.inep.gov.br/web/ guest/sinopses-estatisticas-da-educacao-superior. Accessed on: Aug.15, 2018.

LIMA, E. E.; MACHADO, L. R. S. Reuni e expansão universitária na UFMG de 2008 a 2012. Educação \& Realidade, Porto Alegre, v. 41, n. 2, p. 383-406, 2016. https://doi.org/10.1590/2175-623654765

MACEDO, D. B. et al. Formação do acadêmico do curso de agronegócio: da evasão a empregabilidade. In: CONGRESSO BRASILEIRO DE ZOOTECNIA ZOOTEC 2015: DIMENSÕES TECNOLÓGICAS E SOCIAIS DA ZOOTECNIA, 15., 2015, Fortaleza. Anais[...] Brasília, DF: Associação Brasileira de Zootecnistas, 2015.

MELLO, A. B. F. Consulta sobre a abrangência da habilitação do curso de licenciatura plena em Ciências da Natureza e Matemática, ministrado pela Universidade Federal de Ouro Preto, unidade de Santa Bárbara/MG. Brasília, DF: Ministério da Educação, 2008. Avaliable from: http://portal.mec.gov.br/ cne/arquivos/pdf/2008/pces054_08.pdf. Accessed on: May12, 2019.

MOLINA, M. C.; ROCHA, M. I. A. Educação do campo: história, práticas e desafios no âmbito das políticas de formação de educadores: reflexões sobren o PRONERA e o PROCAMPO. Revista Reflexão e Ação, Santa Cruz do Sul, v. 22, n. 2, p. 220-253, July/Dec. 2014.

MORAES, M. C. B.; KALNIN, G. F. Qualidade na educação superior: uma revisão teórica da evolução conceitual no campo da educação superior. Ensaio: Avaliação e Políticas Públicas em Educação, Rio de Janeiro, v. 26, n. 100, p. 530-51, July/Sept. 2018. https://doi.org/10.1590/s0104-40362018002601114

MORGADO, P. R. et al. Avaliação do curso e da situação profissional e acadêmica dos egressos da gestão ambiental da ESALQ/USP. Remea: Revista Eletrônica do Mestrado em Educação Ambiental, Carreiros, v. 27, p. 69-83, July/Dec. 2011. https://doi.org/10.14295/remea.v27i0.3252

NAZARETH, H. R. S. Curso básico de estatística. 12. ed. São Paulo: Afiliada, 1999. 
PRADO FILHO, F. J. et al. Inserção do engenheiro ambiental da escola de minas da Universidade Federal de Ouro Preto (Ufop) no mercado de trabalho. Ouro Preto, MG: Associação Brasileira de Engenharia Sanitária e Ambiental, 2013.

PRESTES, E. M. T.; FIALHO, M. G. D. Evasão na educação superior e gestão institucional: o caso da Universidade Federal da Paraíba. Ensaio: Avaliação e Políticas Públicas em Educação, Rio de Janeiro, v. 26, n. 100, p. 869-889, July/Sept. 2018. https://doi.org/10.1590/s0104-40362018002601104

RIVA, C.; SCHOENINGER, A. K. Inserção dos egressos do curso de administração no mercado de trabalho. Unoesc \& Ciência - ACSA, [s. l.], v. 6, n. 1, p. 107-14, June 2015.

SANTOS, J.; SILVA M. A. P.; SANTOS, G. S. Evasão na educação superior: um estudo preliminar na UFRB. In: COLOQUIO DE GESTIÓN UNIVERSITARIA, 13, 2011, Cruz das Almas. Anais[...] Florianopolis, SC: Universidade Federal de Santa Catarina, 2013.

SANTOS NETO, A. A. D.; AZEVEDO, D. B. D. Evolução e perspectivas do curso de graduação em gestão do agronegócio no Brasil: perfil dos estudantes e profissionais. E\&G: Revista Economia e Gestão, Belo Horizonte, v. 13, n. 32, p. 107-129, May/Aug. 2013. https://doi.org/10.5752/P.1984-6606.2013v13n32p107

SARAIVA R. C. F.; DINIZ. J. D. A. S. Universidade de Brasilia: trajetória da expansão nos 50 anos. Brasília, DF: Movimento, 2012.

SILVA, J. M; NUNES, R. S.; JACOBSEN, A. L. O programa de acompanhamento dos egressos da Universidade Federal de Santa Catariana: a definição do perfil dos estudantes no período 1970 - 2011. In: COLÓQUIO INTERNACIONAL SOBRE GESTÃO UNIVERSITÁRIA NA AMERICA DO SUL, 11, 2011, Florianópolis. Anais[...] Florianopolis, SC: Universidade Federal de Santa Catarina, 2011.

SOUSA, A. P. R.; COIMBRA, L. J. P.; SOUSA, M. S. Reforma universitária e as consequências para a qualidade da educação superior pública: o caso da Universidade Federal do Maranhão. In: JORNADA INTERNACIONAL DE POLÍTICAS PÚBLICAS, 5, 2011, São Luís. Anais[...] São Luís, MA: Universidade Federal do Maranhão, 2011.

TEIXEIRA, D. E. et al. Avaliação institucional em ciências biológicas nas modalidades presencial e a distância: percepção dos egressos. Ensaio: Avaliação e Políticas Públicas em Educação, Rio de Janeiro, v. 23, n. 86, p. 159-80, Jan./Feb. 2015. https://doi.org/10.1590/S0104-40362015000100006 
TOKARNIA, M. Novo presidente terá de garantir mais vagas no ensino superior. Agência Brasil, Sept. 7, 2018. Avaliable on: https://d.emtempo. com.br/cotidiano-pais/119726/novo-presidente-tera-de-garantir-mais-vagasnoensino-superior. Accessed on: Feb. 15, 2018.

UNIVERSIDADE DE BRASÍLIA - UNB. Novo anuário estatístico da UnB: período 2010 a 2014. Brasília, DF, 2015.

VIZIA, B. Para cada ano de estudo, renda aumenta 15\%, mostra a Fundação Getúlio Vargas (FGV). Gazeta Mercantil Online - SP, 2008 Oct. 10.

\section{Information about authors}

Alexandre Nascimento de Almeida: Professor of the Graduate Program in Public Management, Environmental Sciences and Water Resources Management and Regulation at Universit of Brasilia. Contact: alexalmeida@unb.br

(iD) http://orcid.org/0000-0002-9113-0729

Ivonaldo Vieira Neres: Master's degree in Public Management at the University of Brasília. Server at the same university. Contact: ivonaldo@unb.br

iD http://orcid.org/0000-0002-5315-9635

André Nunes: $\mathrm{PhD}$ in Economics of the University of Brasília. Professor of Graduate Program in Public Management at the same university. Contact: andrenunes@unb.br

(iD) http://orcid.org/0000-0001-9928-6245

Celso Vila Nova de Souza Júnior: $\mathrm{PhD}$ in Economics of the University of Brasília. Professor of the Graduate Program in Public Management at the same university. Contact: celso.vilanova@gmail.com

(iD) http://orcid.org/0000-0003-3623-9251 